\title{
A Comparative Study on The Perception of Forest Landscape Using LIST Method Between University Students of Japan and Indonesia
}

\author{
Prita Indah Pratiwi ${ }^{1 *}$, Bambang Sulistyantara ${ }^{2}$, Andi Gunawan ${ }^{2}$, Katsunori Furuya ${ }^{3}$
}

\author{
${ }^{1}$ Graduate School of Bogor Agricultural University, Dramaga Main Road, Campus IPB Darmaga, Bogor, Indonesia 16680 \\ ${ }^{2}$ Department of Landscape Architecture, Bogor Agricultural University, Jl Meranti Campus IPB Darmaga, Bogor, Indonesia \\ 16680 \\ ${ }^{3}$ Division of Environmental Science and Landscape Architecture, Graduate School of Horticulture, Chiba University. 648 \\ Matsudo, Matsudo, Chiba, Japan 271-8510
}

\section{Received June 4, 2014/Accepted December 18, 2014}

\begin{abstract}
Forest is not only assessed for timber production, but also for public interests. It is not easy to measure the multiple functions and existence values that forests represent to local residents. The purposes of this research were to classify landscape image aspects of students using LIST (Landscape Image Sketching Technique), to know students' attributes influencing perception, and to formulate the differences of forest landscape characters. The research was conducted in three stages: landscape image survey, landscape image analysis, and forest landscape interpretation. LIST method was applied to classify landscape image aspects. Chi-square test was applied to examine the significant differences between students of Japan and Indonesia to perceive forest landscape, while cluster analysis was applied to characterize forest landscape. The results showed that 10 prominent components were detected in both countries. The only attribute influencing perception for Indonesian students was gender. Japanese students categorized forest type into needle leaf, broadleaf, and unknown forest type, while Indonesian students classified forest type into broadleaf and unknown forest type. The results of this study might be useful as a guidance for forest landscape design in Japan and Indonesia.
\end{abstract}

Keywords: chi-square test, cluster analysis, forest, LIST, perception

*Correspondence author, email: chazter610@yahoo.com,tel.: +62-813-82426570

\section{Introduction}

In the recent years, the forests in Asia in particular have been strongly affected by over-harvesting, over-grazing, pests and diseases, high global temperatures, floods, droughts, storms, air pollution, and forest fires (Inoue 2003). A number of initiatives have suggested forest policy reforms and the need for the sustainable forest management has been widely recognized and encouraged. As Schmithüsen (1995) described, the lack of consensus on a balance among global, national and local demands becomes a major obstacle for the advancement of international cooperation in forest policy. Local socio-cultural background is often ignored by global discussion (Rannikko 1999; Marsden 2003; Finger-stich 2005). Whereas in the interest of sustainable forest management, forest is no longer assessed only for timber production, but also for public interests (Kleim \& Wolf 2007), such as amenity, tourism, conservation, even nature's health service (Knight 2000; Li et al. 2006).

It is crucial that people effectively participate in forest planning and management to measure the multiple functions and existing values that forests represent to local residents. Public participation methods reflect the local conditions, carry a lower cost than that other approaches, and they are the key to unlock this situation even in developed countries (Fujiwara 2003). Japan and Indonesia as neighboring countries took part in forest policy reforms and the need for the sustainable forest management. The forest type in Japan and Indonesia is quite different. As Sasse (1998) explained, Japan stretches from north to south with a wide range of climatic zones from sub-alpine, cool-temperate, warmtemperate, and subtropical. Unfortunately, most of famous natural sights in Japan such as Matsushima or the Fuji area have been exploited either by economic progress or poor local management (Sutton 2008). Japan has struggled to define and redefine the boundaries between preservation and exploitation of forest in recent decades. Meanwhile, Indonesia is an archipelago country running from east to west, spanning the evergreen rainforest with regular heavy and deciduous monsoon forest and savanna grassland (McKinnon 1992). Most of developing countries can not solve the problem of limited management resources and high cost derived from scattered sites complicated by the diverse interests of multiple parties in forest management (Fujiwara 2003). Therefore, all countries, regardless of the level of economic development, could adopt public participation methods to keep nature.

Many cognitive approaches to landscape studies discuss the structure of the human response to forest landscape and focused on people's interpretation and understanding of the perceived landscape (Swaffield \& Foster 2000; Karjalainen 
\& Tyrvälnen 2002). Recently, some studies have focused on the influence of specific nature images on landscape preference (Ribe 2002; Van den Berg \& Koole 2006; Pratiwi et al. 2014). Both students of Japan and Indonesia distinguished their landscape preference on natural landscape image experiment using photographs into 25 photos of lake, river, wetland, and forest landscape, meanwhile, their landscape exoticism was put into 48 photos of various landscape types (Pratiwi et al. 2014). Pratiwi and Gunawan (2014) reinforced that the uniqueness and attractiveness of image favored by students were encouraged by perception in assessing certain aspects so that it led to different attitude and behavior which support or not support environmental attitudes. Some factors may lead to differences in environmental attitudes because significant differences were confirmed only between the two research sites in Russia and Minami-Kyushu University in terms of educational history, occupation, experience of travel to Siberia, experience of travel abroad, and number of times of travel. In addition, gender, age, present urbanization level, and past landscape type, which were significant differences from other domestic research sites, did not lead to differences in environmental attitudes (Takayama 2013).

By externalizing landscape image directly as visual information, the variation of students's perception could be understood that it might encourage the preference differences in the way of seeing the landscape. Because of the differences in perception of seeing landscapes and natural enironment, it is necessary to classify landscape image aspects of both students using LIST, to know students' attributes that may influence perception, and to formulate the differences of forest landscape characters. The general hypothesis was that there is a significant difference between students of Japan and Indonesia towards forest landscape, and there is a relationship between students' attributes and forest landscape.

\section{Method}

Landscape Image Sketching Technique (LIST) Landscape Image Sketching Technique (LIST) consists of a combination of a brief sketch of various landscape, keywords reffering to landscape, and short verbal description of landscape done by respondents (Ueda 2009). This method could represent one's view towards spatial environment and linguistic value orientation. Nakamura (1982) in Ueda (2012) explained the most distinctive character of LIST is the analysis of visual data of a scenic sketch. The drawing sketch is a kind of representation of one's landscape image which can be interpreted with some main elements like mental mapping based on the classic idea of gestalt psychology. Ueda also emphasized that the three phases have four Fukei (a Japanese word meaning landscape perception) conditions: (1) identification of landscape elements (through spatial view and linguistic knowledge), (2) structure of personenvironment relationship (as self-orientation), and (3) the meaning (intersubjective values) of place according to how one's intentions are interpreted. Thus, the landscape image is central in the square model and comprises all of the elements (Figure 1).

Time and research object The object of the research was students' memory of forest landscape. In order to assess the perception of forest landscape among different people, university students of Chiba University and Bogor Agricultural University were selected as respondents. The survey took place during February until April 2013.

Data collection and sampling Nowadays, the context of the multiple values of forests, especially for conducting LIST, involves not only merely experts, but also students (Ueda 2006; Pratiwi et al. 2013) and general society or local residents (Ross \& Wall 1999; Ueda 2009). The sampling method applied in this research was non-random sampling technique (purposive sampling) in which the sample selection used the criteria below. The type of respondents selected was independent respondents who were not influenced respectively by the experience of visits to Japan or Indonesia. The students who studied the basics of Environmental Science for at least 2 years were selected because educational history has a major influence on environmental attitudes (Takayama 2013).

The determination of the sample size in this research was 105 students (55 students from Chiba University and 50 students from Bogor Agricultural University). The students from Chiba University consisted of undergraduate and graduate students of Landscape Architecture and Environmental Science Department, Faculty of Horticulture, while the students from Bogor Agricultural University

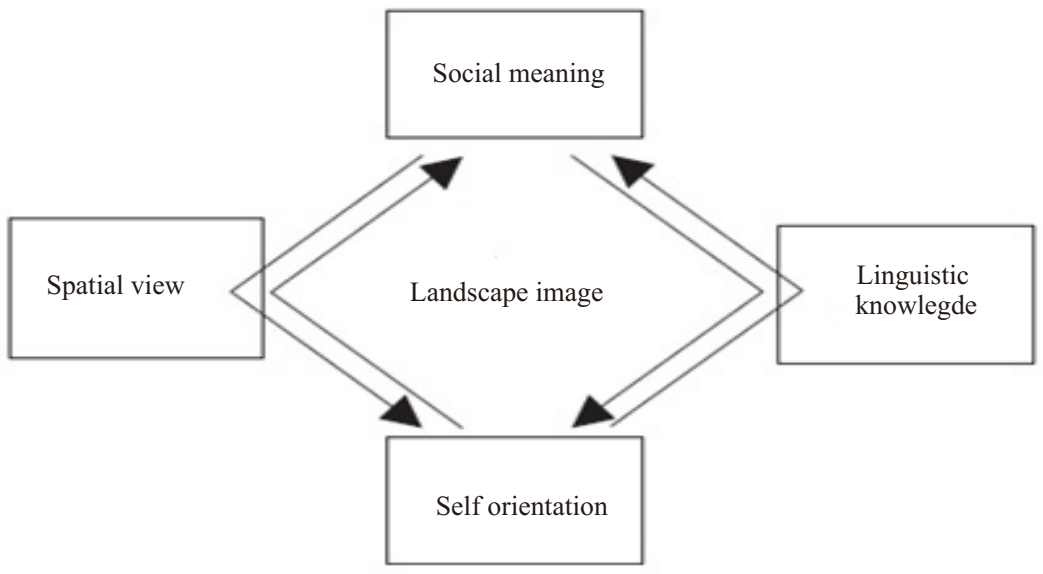

Figure 1 Diagram of landscape image. 
consisted of undergraduate and graduate students of Landscape Architecture Department, Faculty of Agriculture. In terms of sample size, the number of students was sufficient, because the research sample or research object for each country was more than 30 respondents as expressed by Gay and Diehl (1992), Roscoe (1975), and Fraenkel \& Wallen (1993).

The data was obtained through survey using questionnaire and tested to 105 university students. The questionnaire was arranged using their native language for equal understanding of questionnaire as research instrument, distributed by key person in each university, and filled out by students using pen to avoid systematic error for about 15 minutes. This following questions were asked to the students:

\begin{tabular}{|c|c|}
\hline \multicolumn{2}{|c|}{ [Data attributes } \\
\hline 1 & Gender: Male/Female \\
\hline 2 & Age \\
\hline 3 & Nationality \\
\hline 4 & $\begin{array}{l}\text { Education: Undergraduate/Graduate/Post } \\
\text { doctoral/Other }\end{array}$ \\
\hline 5 & $\begin{array}{l}\text { Major: Technical/Environmental science/ } \\
\text { Humanity/Other }\end{array}$ \\
\hline 6 & Occupation: Student/Faculty staff/Other \\
\hline 7 & $\begin{array}{l}\text { Urbanization level: City center/Urban area/ } \\
\text { Suburban area/Rural area }\end{array}$ \\
\hline 8 & $\begin{array}{l}\text { Type of landscape in the region of your stay: } \\
\text { Plain/Mountain/Coastal/Basin/Other }\end{array}$ \\
\hline 9 & $\begin{array}{l}\text { Experience of journey: Domestic, Indonesia, Japan, } \\
\text { Other foreign country }\end{array}$ \\
\hline 10 & $\begin{array}{l}\text { You will refine the type of the region, where you } \\
\text { lived up to } 18 \text { years: City center/Urban } \\
\text { area/Suburban area/Rural area }\end{array}$ \\
\hline 11 & $\begin{array}{l}\text { The type of lanscape of the region in which you } \\
\text { lived up to } 18 \text { years: Plain/Mountain/Coastal/ } \\
\text { Basin/Other }\end{array}$ \\
\hline
\end{tabular}

II Free association survey of landscape image sketches of forest in Japan and Indonesia

We aim to compare the imagery of 'forest' between Japan and Indonesia. This investigation analyzes the linguistic keywords and visual sketching of your forest image. Please fill out the form with the pen (Total 15 minutes).

1 What do you imagine with the word 'forest'? About your own forest image, please answer the following three questions.

2 Please fill in the blanks with some keywords about your free association 'forest' (min 3 words)-(2 minutes).

3 Please explain the situation of your forest image with some sentences ( $\max 100$ words)-(5 minutes).

4 Please make a brief sketch of your forest image (with keywords if necessary-(5 minutes).

Data analysis procedures LIST is one of the effective methods to analyze the meaning of environment. Based on Lucas (1991), the research procedure for developing a design concept consists of landscape image survey, landscape image analysis, and forest landscape interpretation (Figure 2).

\section{Landscape image survey}

1 Key words and text of forest

The students were asked to imagine forest and the words related to forest. Then, the students gave some keywords relating to forest and explained the situation within forest based on the words they had chosen with a short description. This part was the first step in applying the LIST method described in Ueda $(2006,2009,2010)$, Ueda et al. (2012), and Mizuuchi et al. (2013).

2 Landscape image sketch of forest

The same students drew a brief sketch of their forest image. Generally, the meaning of the environment might be only interpreted through verbal description. Using landscape image sketch, it is expected to be a method that can complement incomplete data.

3 Students' attributes

For LIST, it was necessary to clarify attributes of students such as gender, age, past landscape type, present landscape type, past urbanization level, present urbanization level, and experience of journey. As Takayama (2013) suggested, these possible factors may lead to differences in environmental attitudes between research sites in Japan and Indonesia. It was expected that the landscape types and physical changes over time in the forests of the home country would be related to perception.

\section{Landscape image analysis}

1 Analysis of visual and verbal data

Visual and verbal data were analyzed in three phases of LIST. The analysis was implemented onto 4 fukei conditions (landscape image aspects), namely (a) identification of landscape elements (through spatial view and linguistic knowledge), (b) structure of personenvironment relationship (through self-orientation), and (c) the meaning of place (through social meaning). This method provides new insights into the understanding of public image through landscape perception (Ueda 2010).

1.1 Linguistic knowledge

Landscape elements were labelled verbally and identified visually: understory plant, terrain, trail, creature, water, artificial object, people, and sky. First, landscape elements were identified based on words and shapes. Based on the landscape elements, the types of forest in Japan and Indonesia could be classified into mixed forest, needle leaf forest, broadleaf forest, unknown forest, and fallen tree type.

1.2 Spatial view

View angle and distance were classified visually according to the visual appearance of each landscape element. The represented visual appearance of each landscape element could be understood in terms of view angle and distance indicating which part of landscape was captured from certain viewpoint. The size of tree symbols and texture were classified into four groups: close-up, sideway, bird eye, and distant view.

1.3 Self-orientation

The relationship between the various elements and the 


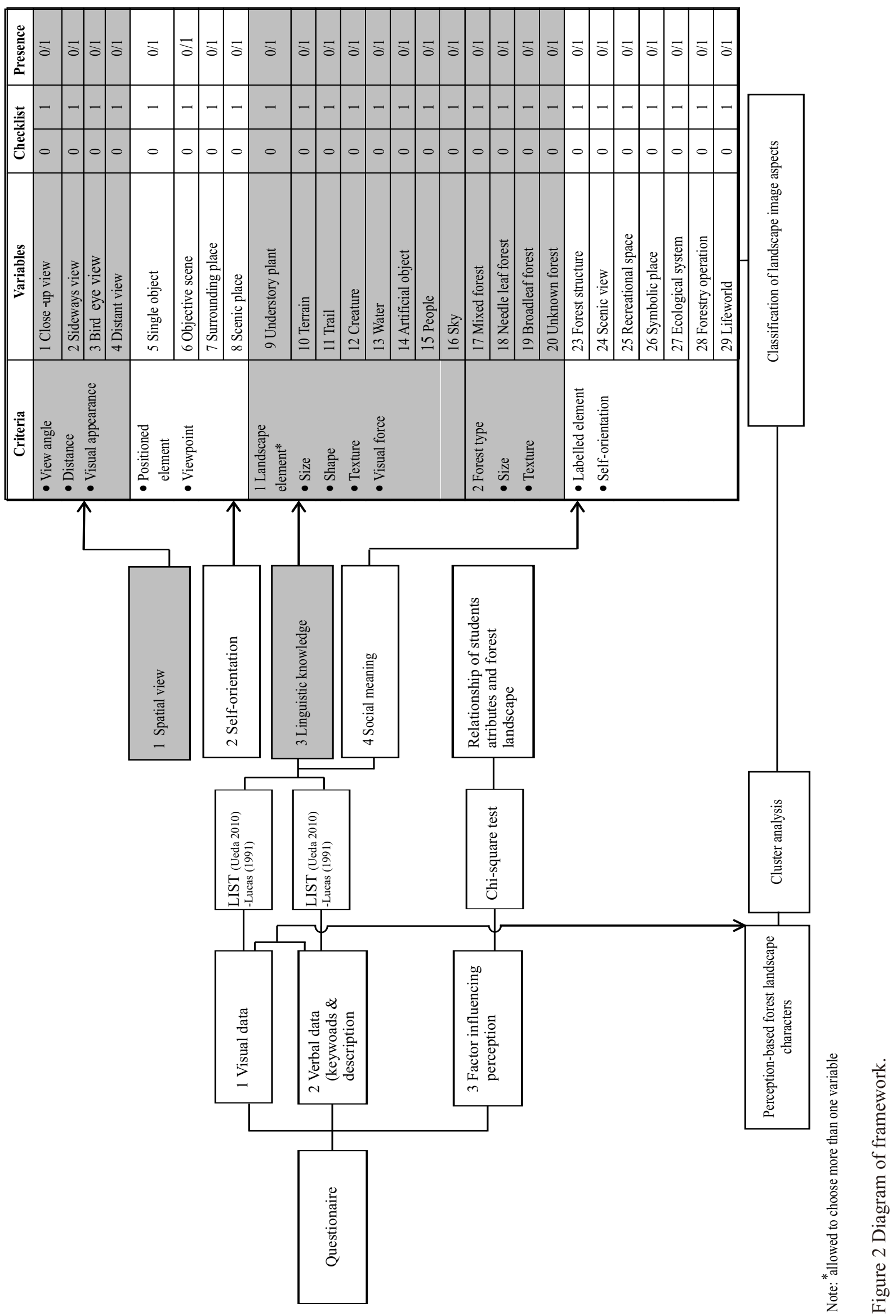


viewpoints showed how each student perceived selforientation in his or her landscape image sketch. This relationship reinforced the representation of a person-environment relationship. The results were classified into four groups: single object, objective scene, surrounding place, and scenic place.

\subsection{Social meaning}

The meaning of the forest was interpreted visually and verbally in relation to landscape element and selforientation. This personal meaning showed the meaning of landscape as a place with various interests. The pattern of landscape image of certain social group was categorized into eight groups: forest structure, scenic view, recreational space, symbolic place, ecological system, forestry operation, and lifeworld.

Finally, each landscape image sketch was classified into landscape image aspects using checklist method. The presence of the variables in the landscape image sketches was defined as ' 1 ', while ' 0 ' indicated the absence of the variables in the landscape image sketches. Then, chisquare test was applied to analyze the significant differences between students of Japan and Indonesia in how they perceived forest landscape. The only significant variable at $p<0.05$ was discussed to characterize the landscape images in Japan and Indonesia.

2 Analysis of factors influencing perception

The purpose of this analysis was to examine the relationship among students' attributes and the forest landscape. The questionnaire consisted of 7 variables, namely, gender, age, past landscape type present, landscape type, past urbanization level, present urbanization level, and experience of journey. Chi-square test was applied to examine these relationships.

3 Cluster analysis of perception

Having been classified into landscape image aspects, then the data consisting of 28 variables of landscape image aspects was analysed using cluster analysis. Cluster analysis using Wards method and Jaccard similarity index was applied to characterize forest landscape. Jaccard's coefficient is measurement of asymmetric information on binary variables based on the presence and absence of data and is calculated as the mean of the clusters (He \& Barclay 2000). The negative value and non-existence are not counted in this case, so Jaccard similarity index will not represent double absence. The cluster analysis step was conducted as follows (Supranto 2010): (1) defining problem, (2) choosing measure of distance, (3) selecting clustering procedure, (4) considering the number of cluster, and (5) interpreting profile of cluster.

Forest landscape interpretation Forest landscape interpretation in Japan and Indonesia was formulated and derived from cluster analysis. The differences of forest landscape characters were considered through the important principles of forest landscape design including shape, visual force, scale, diversity, and unity (Lucas 1991). The interpretation was expected to be useful for guidance of forest landscape design in Japan and Indonesia.

\section{Results and Discussion}

Classification of landscape image aspects Prominent component of forest landscape using LIST (Ueda 2010) was classified and interpreted into landscape appraisal as basis for developing design concept (Lucas 1991). A total of 10 prominent components was perceived by Japanese and Indonesian students (Table 1). Prominent component perceived by Japanese students was landscape elements, while by Indonesian students it was social meaning. In further details, landscape image of Japan had forest usage characterized by trail, people, surrounding place, and recreational space, while landscape image of Indonesia had natural components and views characterized by understory plant, broadleaf forest, and sideway view. Indonesian students preferably sketched high trees with the biodiversity reflected the tropical broadleaf tree, athough there are only few needle leaf tree in the area where the students live. The image sketches do not always reflect the actual landscape and local native vegetation, but imply the subject's cultural perspective of the forest (Ueda 2012).

In landscape image of Japan, landscape elements including trail and people played an important role to encourage forest usage, thus Japanese students had environmental attitude towards the natural environment (Takayama 2010). Japan has cultural and historical influences in the way of viewing landscape (Higuchi 1989) characterized by temple (otera) and shrine (jinja) in remote distance from the settlement. Japanese people used forest as religious activities and recreational space. Meanwhile, Indonesian people did their religious activities in mosque, church, shrine, or temple located in the center of settlement.

In landscape image of Indonesia, social meaning that was expressed by forest structure and scenic view indicated important factors in influencing forest design, namely, forest stands, and aesthetic factors. Syaukani (2005) reinforced that the higher vegetation diversity index, the higher diversity in forest structure among the other areas. It showed that forest structure implied the variation in age, species, and management regimes (Lucas 1991). Moreover, nature landscape painting in Indonesia, especially in Abdullah Soerjo Soebroto's painting consists of various complementary attributes such as dramatic cloud, yellowish ricefield, layered mountainuous as middle ground and huge mountain as background (Ueda 2012; Hilary and Hujatnika 2013). This diversity of sceneries and the unity of local attributes are identified as the aesthetic factors in the forest (Lucas 1991). In this regard, prominent components based on LIST were explained further and they were in line with landscape appraisal.

Factors influencing perception In landscape image of Japan, age, landscape type, and urbanization level had relationship with most of social meaning variables. Forest structure was perceived as social meaning by students living in present plain landscape type. Various types of scenery featuring middle ground and background in the same scene (scenic view) were perceived by students of 19-26 years old, students living in past and present suburban area. Reffering to Pratiwi (2013), landscape type was recognized and categorized by Japanese students into different distance and 
view angle, namely, wetland in close-up and distant view, and forest in close-up and distant view. Whereas kodama was drawn as symbolic place describing a spirit living in a tree by students living in past rural area. In animated film, kodama appears like white humanoids with large, rattling heads, and has mask-like features, moreover, it is similar to bobbleheads like what Japanese students sketched in their image sketch. In Heian period dictionary, the Wamyou Ruijushou, tree gods are believed with mysterious supernatural power because people will be cursed if they attempt to cut it down.

In landscape image of Indonesia, gender, age, landscape type, and urbanization level had relationship with most of linguistic knowledge variables. The understory plant was perceived as landscape element by students living in past plain landscape type which is shown in shifting cultivation in the forest since pre-colonial period of Netherlands (Prabowo et al. 2010). Male students have more experiences and interests in outdoor recreation (Lorber 2010) such as hiking or mountain biking than female students do, thus terrain was drawn by them as one of landscape elements in their forest sketch. The creature was perceived landscape element by students living in present basin landscape type and present suburban area. Moreover, the sky was perceived as landscape element by students living in present suburban area. The mixed forest was perceived as forest type by female students, students living in present basin landscape type, and students in past rural area. It was in line with Sears et al. (1991) that female students tend to interact with everyone or

Table 1 Prominent components of landscape image aspects

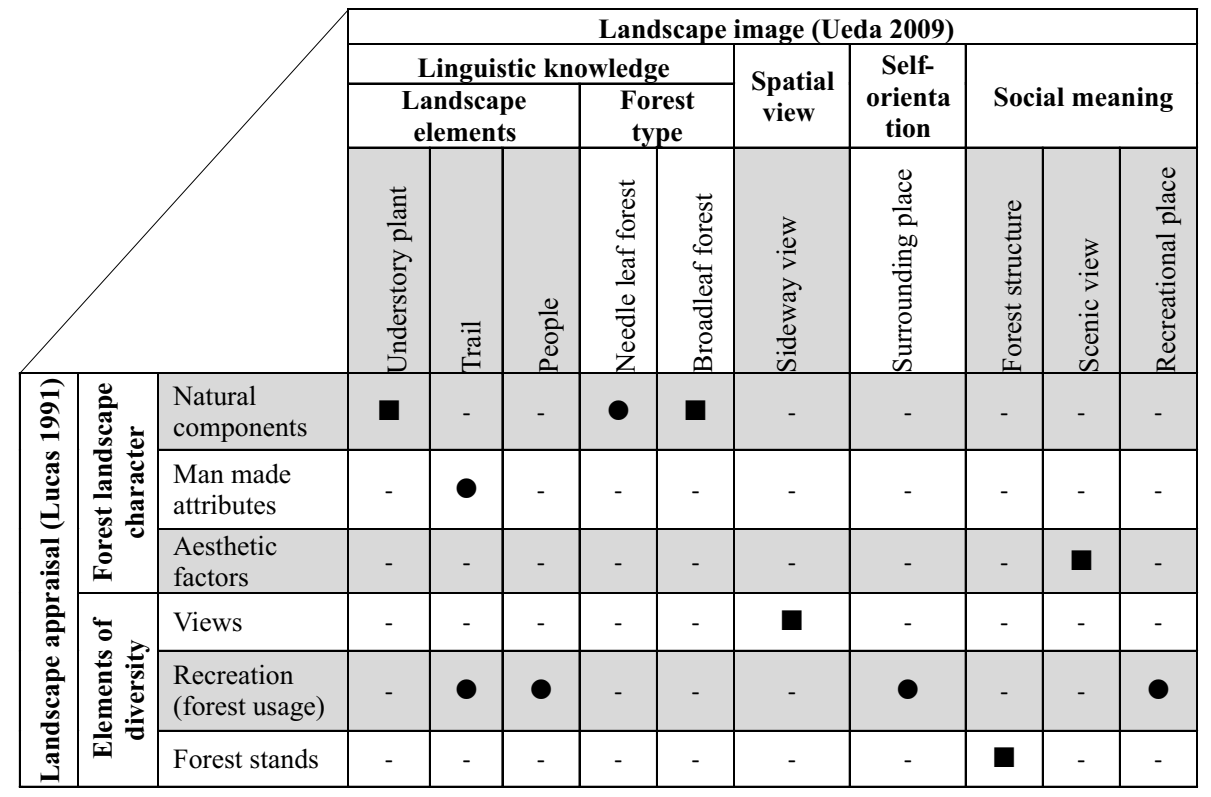

Note: Significant components in Japan (๑), Significant components in Indonesia (ם), Insignificant components (-)

Table 2 Prominent factors influencing perception

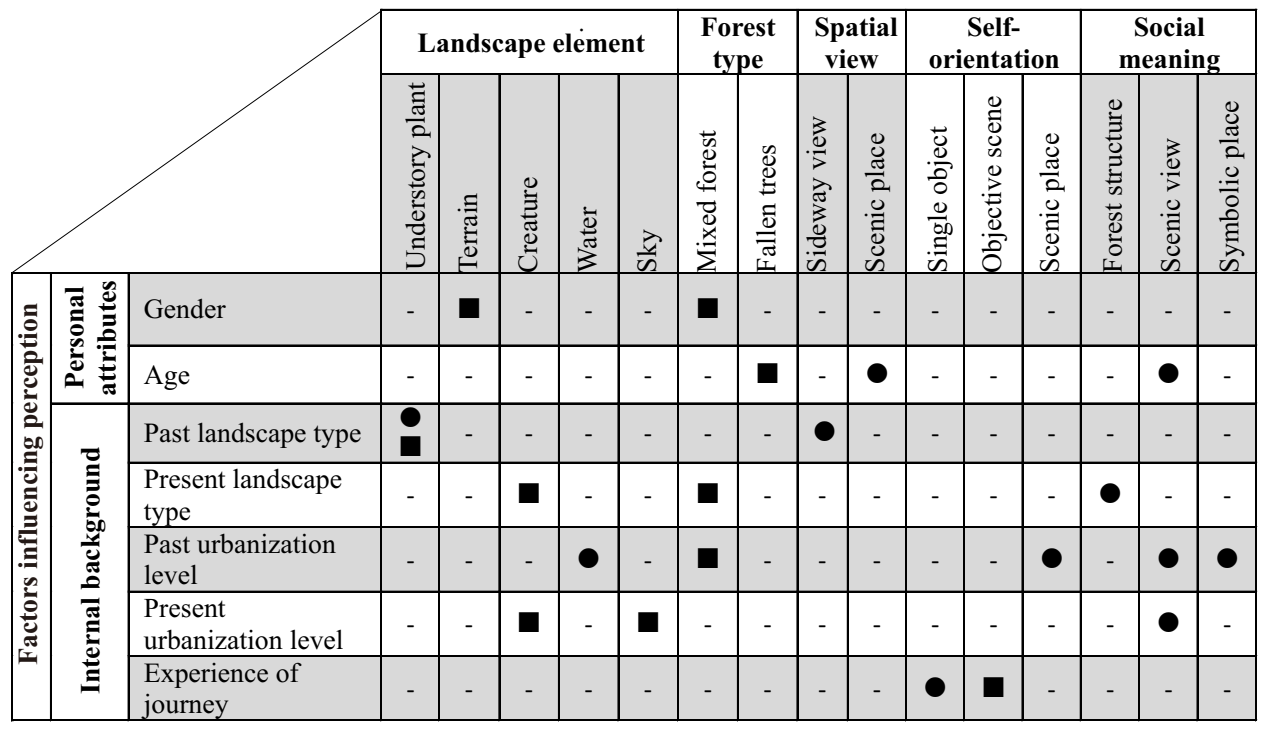

Note: Significant factors in Japan (๑), Significant factors in Indonesia (ם), Insignificant factors (-) 
environment such as forest in closer distance than male students do. Fallen trees were perceived by students of 37-45 years old reinforced by Dolphin (1994) that the higher age the greater distance people interact with their environment. It could be concluded that there is a relationship between students' attributes and forest landscape (Table 2).

Forest landscape characters Recognition of perception as a biological process underscored another important point: perception entailed symbolic representations (Blake \& Sekuler 2006), thus students' perception reflected forest landscape characters in their countries. Cluster analysis using Wards method and Jaccard distance was applied to characterize forest landscape. In this hierarchical clustering, Jaccard distance was used as criteria. The negative value and non-existence are not counted in this case, so it will not represent double absence. Japanese students distinguished forest characters into five clusters, while Indonesian students distinguished forest characters into four clusters (Figure 3 ). The classification of potential landscape image variables in creating a cluster profile was calculated using range formula: The level of the potential landscape image variables was divided into highly potential (mean score 0.68-1), moderately potential (mean score 0.34-0.67), and marginally potential (mean score $0-0.33$ ). The primary point characterizing Japanese cluster was environmental attitude towards the natural environment characterized by trail and people with recreational activities in the forest (Figure 4), while the primary point characterizing Indonesian cluster was scenic natural environment (Figure 5).

Interpretation of Japanese cluster

1 Broadleaf forest type with water in close up view

The first cluster consisted of 10 students. The characteristic of this cluster was determined by broadleaf forest type with natural component of water. A place as scenery without spatial continuity from the viewpoint (scenic view) was created by the combination of various landscape elements (objective scene) that creates a locally distinct character (Elands et al. 2004). Scenic view was recognized not only from a distant view, but also from close-up view.

2 Diverse forests type with understory plant in close-up view

The second cluster consisted of 10 students. The characteristic of this cluster was determined by diverse forests type with natural component of understory plant as cluster of elements without words concerning forest usage. This characteristic was similiar to the first cluster characterized by the absence of forest usage. As Ueda (2012) explained, single object and forest structure were perceived sequentially by students as self-orientation and social meaning variables which they did not include the representation of the viewer's subjective attitudes and activities (Ueda 2012).

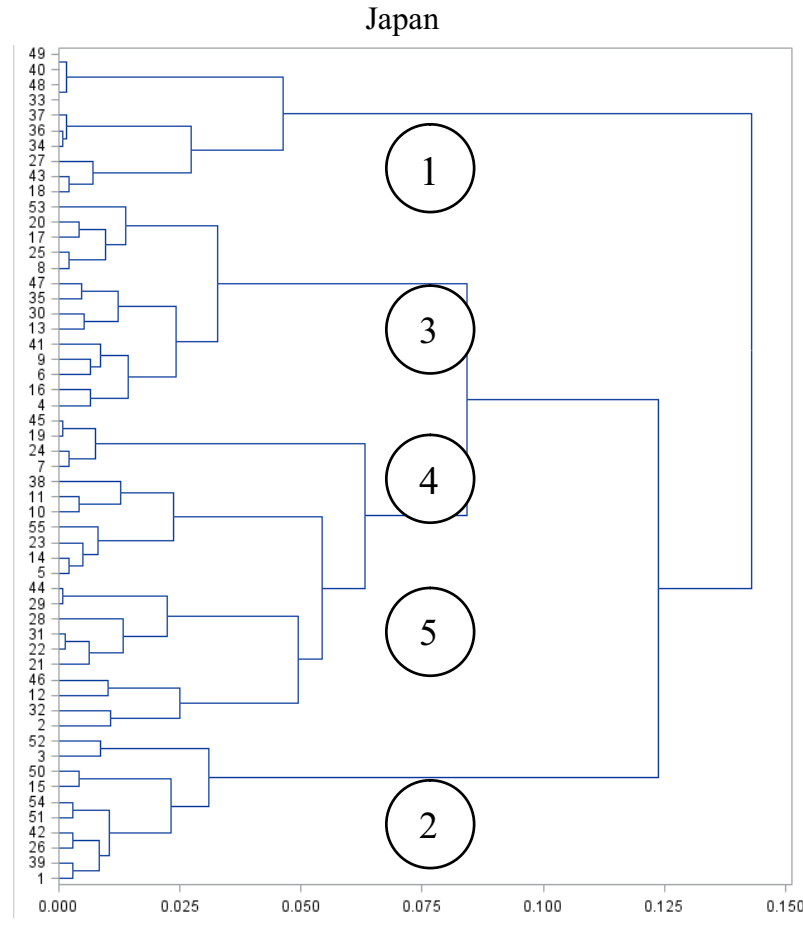

(1) Broadleaf forest with water in close-up view, (2) diverse forests with understory plant in close-up view, (3) unknown forest with trail in diverse views, (4) needle leaf and unknown forest with people in sideway view, and (5) broadleaf forest with creature in bird eye view

Figure 3 Dendogram of Japanese and Indonesian cluster.

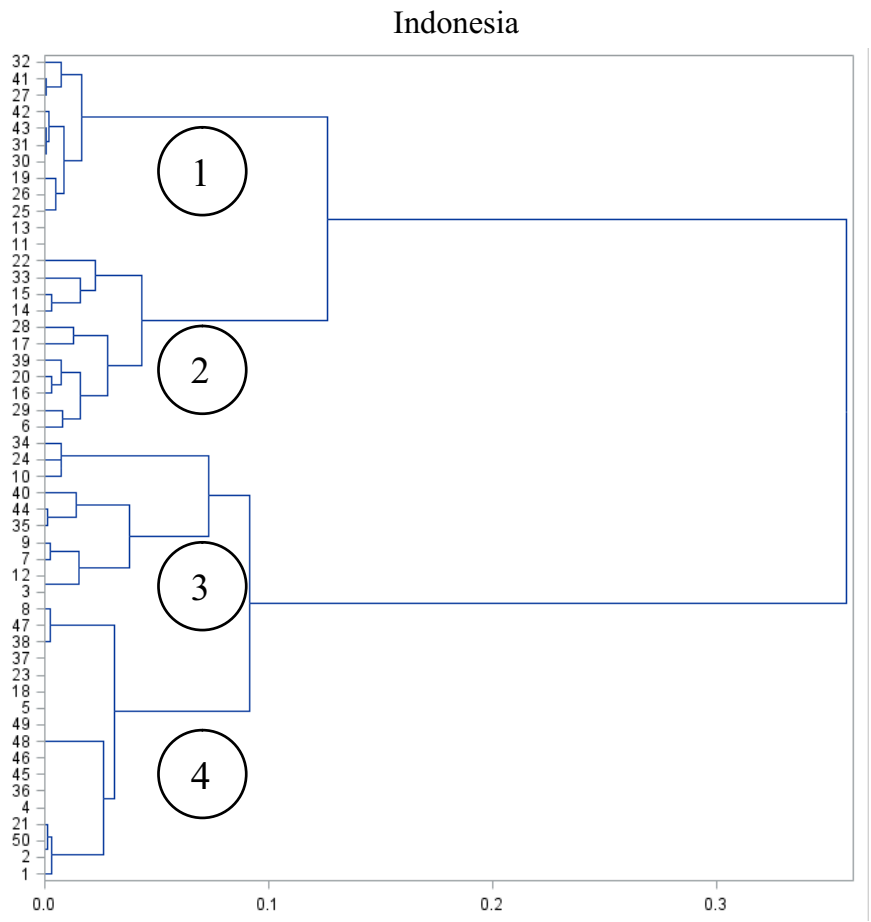

Broadleaf forest with understory plant and other characteristics: (1) water in bird eye view, (2) terrain in sideway view, (3) creature in close-up and sideway view, and (4) unknown forest in sideway view 


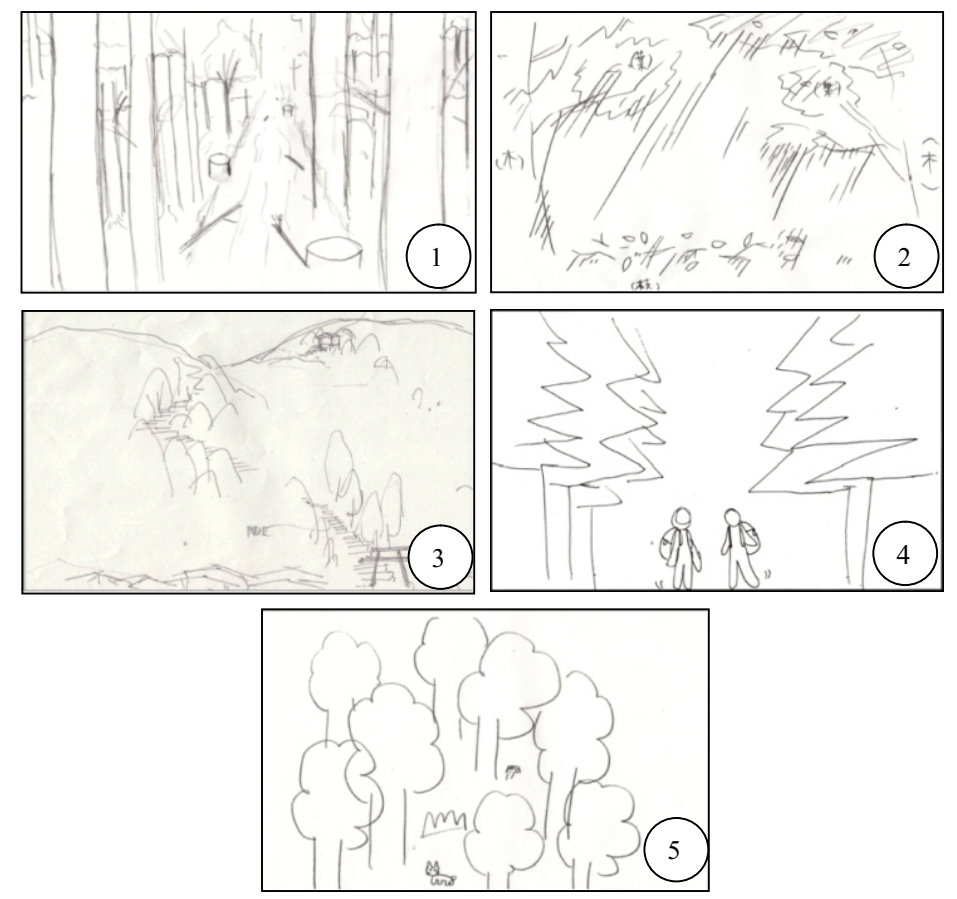

Figure 4 Forest landscape sketch of Japanese cluster. (1) Broadleaf forest with water in close up view, (2) diverse forests with understory plant in close up view, (3) unknown forest with trail in diverse views, (4) needle leaf and unknown forest with people in sideway view, and (5) broadleaf forest with creature in bird eye view.
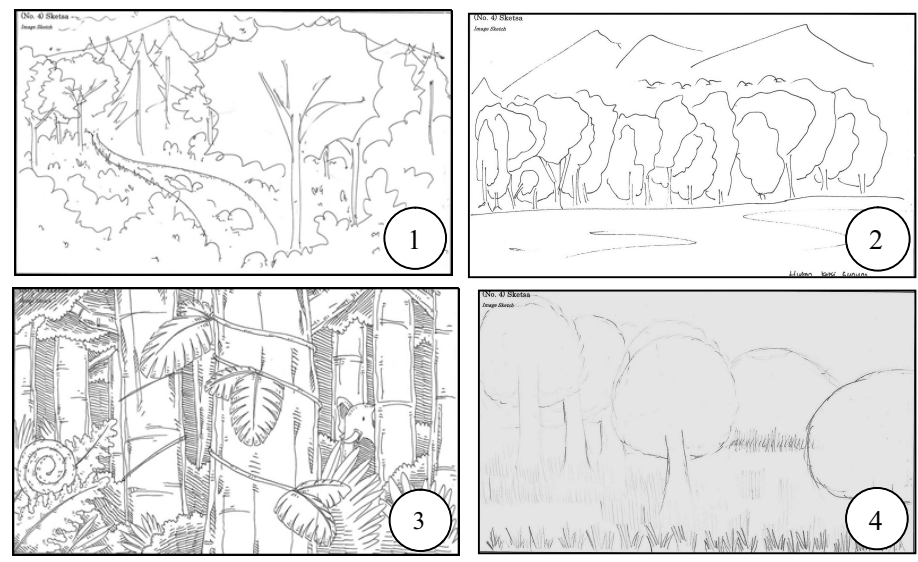

Figure 5 Forest landscape sketch of Indonesian cluster. Broadleaf forest with understory plant and the other characteristics: (1) water in bird eye view, (2) terrain in sideway view, (3) creature in close-up and sideway view, (4) unknown forest in sideway view.

3 Unknown forest type with trail in diverse views

The third cluster consisted of 14 students. The characteristic of this cluster was determined by unknown forest type with human attributes of trail and people, and natural component of understory plant. The relationship between various elements and the body-subject (viewpoint) in a frame implied that the students perceived surrounding place whose both variables of elements and viewpoint mainly describing recreational space as one of forest's services in quality of life (Elands et al. 2004).

4 Needle leaf and unknown forest type with people in sideway view

The fourth cluster consisted of 4 students. The characteristic of this cluster was determined by needle leaf and unknown forest type with human attribute of people. This cluster was almost similiar to the third cluster in which people also influenced the forming of recreational space as one of social meaning variables. The difference between these clusters was that a sum of trees became merely a single object in the forest.

5 Broadleaf forest type with creature in bird eye view The last cluster consisted of 17 students. The characteristic of this cluster was determined by broadleaf forest type with natural components consisting of creature, understory plant, water, and terrain and human attribute consisting of people. Although this cluster was characterized by various elements, the diversity of wildlife and topography became a cluster of elements 
(single object). Consequently, recreational space and ecological system was perceived by students as social meaning variables.

\section{Interpretation of Indonesian cluster}

1 Broadleaf forest with water and understory plant in birds eye view

The first cluster consisted of 12 students. The characteristic of this cluster was expressed by broadleaf forest type with natural components of water, understory plant, and terrain. The combination of various landscape elements identified by diverse sceneries (scenic view) and viewpoint allowed the students to see the forest as scenic place. As Satyatama et al. (2010) has demonstrated, this type of scenery was found as one of attracting factor for travellers in travelling to naturebased tourism area, although the accessibility to the natural attraction in forest is generally inadequate (Purnomo 2011).

2 Broadleaf forest with understory plant and terrain in sideway view

The second cluster consisted of 11 students. The characteristic of this cluster was expressed by broadleaf forest type with natural components of terrain, understory plant, water, and creature. A place as scenery without spatial continuity from the viewpoint (scenic view) was created by the combination of various landscape elements (objective scene). People perceiving scenic view has a wider interest in nature, thus the better place, object, and event type of experience should be guaranteed by planners and managers (Oku \& Fukamachi 2005).
3 Broadleaf forest with understory plant and creature in close-up and sideway view

The third cluster consisted of 10 students. The characteristic of this cluster was expressed by broadleaf forest type with natural components of understory plant and creature. Most of sketches were composed by understory plant (single object) describing forest structure. These sketches were often shown in close-up view and sideway view of forest composed by just trunks of trees (Ueda 2006).

4 Broadleaf and unknown forest with understory plant in sideway view

The last cluster consisted of 17 students. The characteristic of this cluster was expressed by broadleaf and unknown forest type with natural component of understory plant. This cluster was almost similiar to the third cluster characterized by a cluster of understory plant as single object and described as forest structure. This perception was similar to local people's perception that unlogged forest or primary forest is the most important land type because it is a source of livelihood (Liswanti et al. 2004).

Guidance for forest landscape design Based on various perceptions and interpretations of forests from cross-national perspectives, the implication of forest landscape design could be discussed as public interests. Forest interpretation was derived from cluster analysis and based on the principle of forest landscape design (Table 3 and Table 4). The only components categorized in Japanese cluster were people, trail, needle leaf forest, surrounding place, recreational

Table 3 Forest landscape interpretation in Japan

\begin{tabular}{|c|c|c|c|c|c|c|c|c|}
\hline & & & \multirow{2}{*}{ Components } & \multicolumn{5}{|c|}{ Principles of forest landscape design in Japan } \\
\hline & & & & Shape & Visual force & Scale & Diversity & Unity \\
\hline \multirow{15}{*}{ 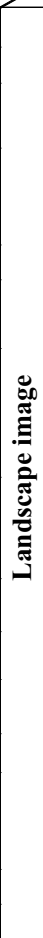 } & \multirow{7}{*}{ 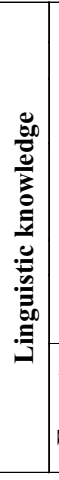 } & \multirow{6}{*}{ 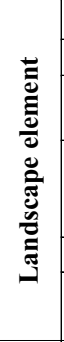 } & People & - & - & Different elevation & - & Different elevation \\
\hline & & & Trail & Organic & - & - & - & - \\
\hline & & & Water & Organic & - & - & $\begin{array}{c}\text { River, lake, } \\
\text { wetland }\end{array}$ & - \\
\hline & & & Understory plant & $\begin{array}{c}\text { Flat, rounded, } \\
\text { mounded, mounded to } \\
\text { rounded }\end{array}$ & - & - & - & - \\
\hline & & & Creature & - & - & - & Fauna & - \\
\hline & & & Terrain & Hilly, undulating & $\begin{array}{c}\text { Peaks, summits, } \\
\text { ridges }\end{array}$ & - & - & Peaks, summits, ridges \\
\hline & & 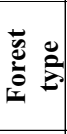 & $\begin{array}{l}\text { Needle leaf, } \\
\text { broadleaf, unknown } \\
\text { forest type }\end{array}$ & $\begin{array}{l}\text { Rounded, columnar, } \\
\text { spreading, weeping, } \\
\text { pyramidal, } \\
\text { unidentified } \\
\end{array}$ & - & - & - & $\begin{array}{l}\text { Rounded, columnar, } \\
\text { spreading, weeping, } \\
\text { pyramidal, unidentified }\end{array}$ \\
\hline & & $\frac{3}{2}$ & Diverse views & - & - & $\begin{array}{l}\text { Narrow, medium, } \\
\text { wide }\end{array}$ & - & Narrow, medium, wide \\
\hline & & పี & Single object & - & - & - & - & Natural environment \\
\hline & & $\stackrel{5}{3}$ & Objective scene & - & - & - & - & Natural environment \\
\hline & & $\bar{a}$ & Surrounding place & - & - & - & - & Environmental attitude \\
\hline & & 0 & Forest structure & - & - & - & Sand structure & - \\
\hline & & 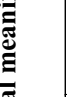 & Scenic view & - & - & - & $\begin{array}{c}\text { Natural features } \\
\text { with distance of } \\
\text { view }\end{array}$ & - \\
\hline & & 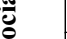 & Recreational space & - & - & - & Open space & - \\
\hline & & & Ecological system & - & - & - & Flora, fauna & - \\
\hline
\end{tabular}


Table 4 Forest landscape interpretation in Indonesia

\begin{tabular}{|c|c|c|c|c|c|c|c|c|}
\hline & & & \multirow[t]{2}{*}{ Components } & \multicolumn{5}{|c|}{ Principles of forest landscape design in Indonesia } \\
\hline & & & & Shape & Visual force & Scale & Diversity & Unity \\
\hline \multirow{12}{*}{ 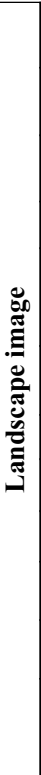 } & \multirow{5}{*}{ 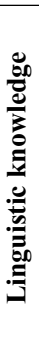 } & \multirow{4}{*}{ 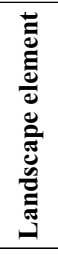 } & Water & organic & - & - & $\begin{array}{l}\text { river, lake, } \\
\text { wetland }\end{array}$ & - \\
\hline & & & Understory plant & $\begin{array}{l}\text { flat, rounded, mounded, } \\
\text { mounded to rounded }\end{array}$ & - & - & $\begin{array}{c}\text { shrub, ground } \\
\text { vegetation species }\end{array}$ & - \\
\hline & & & Terrain & hilly, undulating & $\begin{array}{c}\text { peaks, summits, } \\
\text { ridges }\end{array}$ & - & - & peaks, summits, ridges \\
\hline & & & Creature & - & - & - & fauna & - \\
\hline & & 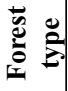 & $\begin{array}{l}\text { Broadleaf forest, } \\
\text { unknown forest type }\end{array}$ & $\begin{array}{l}\text { rounded, columnar, } \\
\text { spreading, weeping }\end{array}$ & - & - & - & $\begin{array}{l}\text { rounded, columnar, } \\
\text { spreading, weeping }\end{array}$ \\
\hline & & $\frac{2}{3}$ & $\begin{array}{c}\text { Sideway view, bird } \\
\text { eye view }\end{array}$ & - & - & medium view & - & medium view \\
\hline & 5 & & Close-up view & - & - & narrow view & - & narrow view \\
\hline & &. & Single object & - & - & - & - & natural environment \\
\hline & & 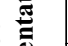 & Objective scene & - & - & - & - & natural environment \\
\hline & & כ) & Scenic place & - & - & viewpoint & - & viewpoint \\
\hline & & & Forest structure & - & - & - & stand structure & - \\
\hline & & $\stackrel{\Xi}{E}$ & Scenic view & - & - & - & $\begin{array}{l}\text { natural features } \\
\text { with distance of } \\
\text { view }\end{array}$ & - \\
\hline
\end{tabular}

Note: see Figure 3

space, and ecological system, while the only component categorized in Indonesian cluster were scenic place. These components varied in a number of ways (variables) including shape and visual force. The ways of organizing components of landscape elements and forest type were used to group components, for example scale, diversity, unity, genius loci. Shape, visual force, scale, diversity, unity, and spirit of the place or genius loci are the most important principle of forest landscape design. They have the greatest impact on perception and have been found to be closely related to good or bad results (Lucas 1991).

The characters of forest landscape could become important goal for formulating the concept of forest landscape design in both countries. Generally, it should keep the balance of natural continuity of landform reflecting the various scale of the landscape from one part to another. It meant that larger variation was needed to form a background to the more diverse pattern of terrain, while smaller details of vegetation, understory plant, water, and trail were more appropriate in foreground or middle ground. In Japan, more spatial improvements were needed for recreational activities. Some considerations of spatial improvement could be applied for forest landscape design in Japan (Lucas 1991) as follows:

a Design of open space

There is two types of open spaces which could be improved as recreational surrounding place, namely, extensive space and linear space. Extensive space could be developed on steeper slopes and at higher elevations such as unplantable land, farm field, felling coupe, and important wildlife site which have significant visual impact. Better views are obtained from recreation routes positioned higher slope. Whereas linear space could be developed by improving the shape, varying the width of the space, and avoiding parallel sides. Besides that, open space is not only needed for recreational space, but also for management, rock outcrops, powerline corridor, open habitat, and unplanted stream side.

b Recreational site and walking route

Historical or cultural element and site might have a recreational role and become historic interest providing the opportunities for interpretation and it contributes to diversity. Moreover, walking route provides and facilitates the accessibility to easily interact with forest such as touching the leaves and water, breathing the fresh air, and having relaxation. In Japan, forest bathing trip is a short and leisurely trip to visit forest park, called Shinrinyoku, which is similar to natural aromatheraphy. This good lifestyle significantly enhances human natural killer cell (NK) activity, increases anti-cancer proteins, and reduces stress (Li et al. 2006, 2008).

In Indonesia, aesthetic quality could be developed by considering the viewpoint out of the forest such as settlements, public roads, footpaths, summits, and so on. Furthermore, the sequence of views on roads and footpaths such as forest edge and roadsides, and the direction and sideway extent of the view from key points should be identified and mapped (Lucas 1991) as follows:

1 Forest edge

In wilder landscape, there should be a gradual change from the solid mass of the forest to open ground. Uniform edges should be varied in scale with the landscape by introducing irregular groups, various species, spacing, and detailed shaping of the edge.

2 Roadsides

Roadside spaces should be planned to dramatize natural features and motorists' sense of movement so that high quality and small scale landsape with potential for recreation should be identified and conserved. The important points that should be considered are entrance and exit of the public road 
Hilary A, Hujatnika A. 2013. Membentangkan kembali alam. Jurnal Tingkat Sarjana Bidang Seni Rupa 2(1):1-8.

into and out of forest, accessible view from vehicle to outside, changes in landscape character which heighten the sense of motion, focal point on the road, minimum man-made, and accessible distant view.

\section{Conclusion}

The prominent components of landscape image in Japan were identified by trail, people, needle leaf forest, surrounding place, and recreational place. The prominent components of landscape image in Indonesia were identified by understory plant, broadleaf forest, sideway view, forest structure, and scenic view. Factors influencing perception consisted of gender, age, past landscape type, present landscape type, past urbanization level, present urbanization level, and experience of journey. The only attribute influencing perception for Indonesian students was gender. Japanese students distinguished forest type into needle leaf, broadleaf, and unknown forest type, while Indonesian students distinguished forest type into broadleaf and unknown forest type.

\section{References}

Blake R, Sekuler R. 2006. Perception. New York: McGrawHill High Education.

Dolphin CZ. 1994. Variables in the use of personal space in intercultural transaction. In: Samovar LA, Porter RE, editors. Intercultural Communication: A Reader. California: Wadsworth, Inc.

Elands BHM, O' Leary TN, Boerwinkel HWJ, Wiersum KF. 2004. Forests as a mirror of rural conditions; local views on the role of forests across Europe. Forest Policy and Economics. 6:469- 482. http://dx.doi.org/10.1016/ j.forpol.2004.01.003.

Ferguson SJ. 2010. Mapping The Social Landscape: Readings in Sociology. New York: McGraw-Hill Companies, Inc.

Finger-stich A. 2005. Social agency in Alpine communal forests-local actors' interactions with communal forests and participation in communal forestry in the French and Swiss Alps [dissertation]. Germany: University of Fueiburg.

Fraenkel JR, Wallen NE. 1993. How to Design and Evaluate Research in Education. Singapore: McGraw-Hill Inc.

Fujiwara T. 2003. Public participation in Japan's forest planning system. In: Inoue $\mathrm{M}$, Isozaki $\mathrm{H}$, editor. People and Forest-Policy and Local Reality in Southeast Asia, the Russian Far East and Japan. Dordecht: Kluwer Academic Publishers. http://dx.doi.org/10.1007/978-94017-2554-5 13.

Gay LR, Diehl PL. 1992. Research Methods for Business and Management. New York: Macmillan.

Higuchi T. 1989. The Visual and Spatial Structure of Landscapes. Tokyo: MIT Pr.
He F, Barclay HJ. 2000. Long-term response of understory plant species to thinning and fertilization in a douglas-fir plantation on southern Vancouver Island, British Columbia. Journal of Forest Research 30:566-572.

Inoue M. 2003. People and Forest-Policy and Local Reality in Southeast Asia, the Russian Far East and Japan. Inoue M, Isozaki $\mathrm{H}$, editor. Dordecht: Kluwer Academic Publishers.

Karjalainen E, Tyrvälnen L. 2002. Visualization in forest landscape preference research: a finnish perspective. Landscape and Urban Planning 59(1):13-28. http://dx.doi.org/10.1016/S0169-2046(01)00244-4.

Kleim JA, Wolf SA. 2007. Toward multifunctional landscapes: cross-sectional analysis of management priorities in New York's northern forest. Rural Sociology 72(3):391-417. http://dx.doi.org/10.1526/00360110 7781799317.

Knight J. 2000. From timber to tourism: recommoditizing the Japanese forest. Development and Change 31:341-359. http://dx.doi.org/10.1111/1467-7660. 00157.

Li Q et al. 2008. Visiting a forest, but not a city, increases human natural killer activity and expression of anticancer proteins. International Journal of Immunopathology and Pharmacology. 21(91):117-127. http://dx.doi.org/10.1080/08923970600809439.

Li Q et al. 2006. Phytoncides (wood essential oils) induce human natural killer cell activity. Immunopharmacol and Immunotoxicol 28:319-333.

Liswanti N, Indawan A, Sumardjo, Sheil D. 2004. Dayak Merap and Punan people's perception of the importance of forest in a tropical landscape, Malinau, East Kalimantan. Jurnal Manajemen Hutan Tropika 10(2):1-13.

Lorber J. 2010. Night to his day. In: Ferguson SJ, editor. Mapping The Social Landscape. New York: McGrawHill Companies Inc. p 96-107.

Lucas OWR. 1991. The Design of Forest Landscape. New York: Oxford University Press.

MacKinnon K. 1992. Nature's Treasurehouse: The Wildlife of Indonesia. Jakarta: PT Gramedia Pustaka Utama.

Marsden T. 2003. Communities in nature, the construction and understanding of forest natures. Sociologia Ruralis 43(3):238-256. http://dx.doi.org/10.1111/1467-9523. 00243 .

Mizuuchi Y, Son Yonghoon, Furuya K. 2013. A Comparative study on forest image between Japan and Korea from the 
perspective of natural resources [abstract]. In: Program Book of The First Asia Parks Congress 2013; 2013 November 13-15; Sendai.

Oku H, Fukamachi K. 2005. The differences in scenic perception of forest visitors through their attributes and recreational activity. Landscape and Urban Planning 75:34-42. http://dx.doi.org/10.1016/j.landurbplan. 2004.10.008.

Prabowo SA, Basuni S, Suharjito D. 2010. Enduring conflict: settlement in Halimun-Salak National Park Area. Jurnal Manajemen Hutan Tropika 16(3):137-142.

Pratiwi PI, Furuya K, Sulistyantara B. 2014. The difference in people's response toward natural landscape between university students of Japan and Indonesia. Jurnal Manusia dan Lingkungan 21(2):247-253.

Pratiwi PI, Gunawan A. 2014. User behavior on specific environment in Bogor Botanical Garden. In: Rahmafitria F, Setiyorini HPD, Sudono A, editors. Eco Resort and Destination Sustainability "Planning, Impact, and Development". $1^{\text {st }}$ International Seminar on Tourism; 2014 October 27-28; Bandung, Indonesia. Bandung: Indonesia University of Education. Pp 143-152.

Purnomo H. 2011. The effect of individual tourist and the mixed marketing to services value on nature-based tourism services. Jurnal Manajemen Hutan Tropika 17(1):10-16.

Rannikko P. 1999. Combining social and ecological sustainability in the Nordic forest periphery. Sociologia Ruralis 39(3):394-411. http://dx.doi.org/10.1111/14679523.00115 .

Ribe RG. 2002. Is scenic beauty a proxy for acceptable management? The influence of environmental attitudes on landscape perceptions. Environment and Behavior 34(6):757-780. http://dx.doi.org/10.1177/001391 602237245 .

Roscoe J. 1975. Fundamental Research Statistics for The Behavioral Sciences. New York: Holt, Rinehart, \& Winston.

Ross S, Wall G. 1999. Evaluating ecotourism: the case of North Sulawesi, Indonesia. Tourism Management 20(6):673-682. http://dx.doi.org/10.1016/S0261 5177(99)00040-0.

Sasse J. 1998. The Forests of Japan. Tokyo: Japan Forest Technical Association.

Satyatama T, Muntasib EKSH, Prasetyo LB. 2010. Planning nature interpretation tracks by the use of geographic information system. Jurnal Manajemen Hutan Tropika 16(3):126-136.
Schmithüsen F. 1995. The Meaning of Forests in a Perspective of Social and Political Development, Swiss Federal Institute of Technology, Department of Forest Sciences, Chair of Forest Policy and Forest.

Sears DO, Freedman JL, Peplau LA. 1991. Psikologi Sosial. Adryanto M, translator. Jakarta: Erlangga. Translation from: Social Psychology. Fifth edition.

Supranto J. 2010. Analisis Multivariat: Arti dan Interpretasi. Jakarta: Rineka Cipta.

Sutton M. 2008. Japan, Mongolia and the potential of ecotourism. Ritsumeikan International Study 21(1):39-55.

Swaffield SR, Foster RJ. 2000. Community perceptions of landscape values in the South Island high country: a literature review of current knowledge and evaluation of survey methods. Science for Conservation 159:1-54.

Syaukani HR, Kusmana C, Alikodra HS, Darusman D, Mudikjo K. 2005. Forest structure and spesies compotition in Taman Raya Bukit Soeharto, East Kalimantan. Jurnal Manajemen Hutan Tropika 11(1):57-66.

Takayama N, Petrova E, Matsushima H, Ueda H, Furuya K, Aoki Y. 2013. Difference in and causes of environmental attitudes between Russia and Japan [abstract]. In: Program Book of Japan Geosciences Union Meeting 2013;2013 August 19-24; Chiba.

Ueda H. 2006. A comparative study on forest image in Japan and German [in Japanese]. Journal of the Japanese Institute of Landscape Architecture 67(5):691-694. http://dx.doi.org/10.5632/jila.69.691.

Ueda H. 2009. A study on resident landscape perception through landscape image-four case studies in Germany and Japan rural communities [dissertation]. Kassel: University of Kassel.

Ueda H. 2010. The Image of The Forest. Südwestdeutscher Verlag für Hochschulschriften AG \& Company KG: Saarbrücken.

Ueda $\mathrm{H}$ et al. 2012. Landscape image sketches of forest in Japan and Rusia. Forest Policy and Economics 19:20-30. http://dx.doi.org/10.1016/j.forpol.2012.01.002.

Van den Berg AE, Koole SL. 2006. New wilderness in the Netherlands: an investigation of visual preferences for nature development landscapes. Land and Urban Planning 78(4):362-372. http://dx.doi.org/10.1016/j. landurbplan.2005.11.006.

Whitten A, Whitten J. 1992. Wild Indonesia. London: New Holland. 